\title{
Pergeseran Paradigma Ijarah dalam Fatwa Ekonomi DSN-MUI dan Implementasinya di Koperasi Syariah NTB
}

\author{
Muhammad Salahuddin, Muslihun, Zaenal Arifin Munir \\ UIN Mataram \\ Jl. Pendidikan No.35, Dasan Agung Baru, Kota Mataram \\ E-mail : salahuddin76@uinmataram.ac.id
}

Diterima: 29 Juni 2019; Direvisi: 19 Desember 2019; Diterbitkan: 20 Desember 2019

\begin{abstract}
Abstrak,
Ekonomi syariah di Indonesia saat ini masih mencari format ideal untuk terus berpartisipasi aktif dalam konteks pembangunan Indonesia. Oleh karena itu DSN-MUI sebagai lembaga 'pengawal' gerak ekonomi syariah di Indonesia berupaya mengembangkan konsep dalam fikih dan disesuaikan dengan realitas ekonomi modern. Ijārah dalam kontek di atas adalah sebagai bagian dari pengembangan dimaksud. Pergeseran paradigma Ijārah pada tataran konseptual fatwa, akan dilihat implentasinya dalam realitas aktivitas mikro ekonomi di lembaga koperasi syariah Nusa Tenggara barat
\end{abstract}

Kata Kunci: Ijārah, fatwa, koperasi syariah

\section{Abstract,}

Sharia economy in Indonesia is still looking for the ideal format participate actively in Indonesia's development context. Therefore the DSN-MUI as an 'bodyguard institution' of sharia economic movements in Indonesia seeks to develop concepts in fiqh and adapted it into modern economic. Ijarah in context above is a part of the intended development. The shifting paradigm of ijarah in fatwa (legal opinion) concept, will be seen its implementation in the reality of micro-economic activities in Koperasi Syariah (Islamic cooperation) at West Nusa Tenggara

Keywords: Ijārah, legal opinion, sharia cooperation

\section{PENDAHULUAN}

Respon masyarakat terhadap ekonomi syariah semakin menguat dengan hadirnya UU. No. 21 tahun 2008 tentang Perbankan Syariah. Kehadiran undang-undang di atas merupakan legal-stand atas operasional sistem syariah dalam bidang ekonomi, dan sekaligus sebagai 'obat' atas kebimbangan masyarakat muslim Indonesia selama puluhan tahun (Sadzali: 1993). Undang-undang di atas pun dikuatkan oleh fatwa DSN-MUI terkait dengan ekonomi. Eksistensi fatwa ini pun diakomodasi secara baik dalam undang-undang dan aturan keuangan dan perbankan syariah di Indonesia, serta dijadikan referensi dalam pengembangan produk layanan jasa keuangan syariah (Salahuddin, 2017: 7). Pada sisi ini, fatwa ekonomi DSN-MUI, walaupun tidak seluruhnya, sudah menjadi bagian dari sistem Indonesia. Yang perlu 
digarisbawahi di sini bahwa islam ekonomi mendapat dukungan penuh, karena mendukung pembangunan nasional (Salahuddin, 2019: 7).

Ekonomi, pada prinsipnya bukan milik kelompok tertentu. Namun pemikiran ekonomi hadir atas dasar realitas (locus-tempus) dan trend yang melingkupi perkembangan sosial masyarakat, yang mencakup aspek budaya, pendidikan, politik, tehnologi, dan lain-lain. Aspek non-ekonomi di atas adalah dependent variable yang mempengaruhi aktivitas ekonomi. Kapitalisme, sosialisme, dan ekonomi syariah hadir dalam realitas masyarakat yang berbeda; sistem nilai, sistem budaya, sistem sosial, sistem politik. Dengan demikian, paham ekonomi yang dikembangkan juga didasarkan atas realitas yang berkembang terus berubah. Namun yang perlu digarisbawahi bahwa semua mazhab ekonomi, dan dengan berbagai pendekatan yang ada di dalamnya bertujuan untuk mewujudkan state walfare, atau dalam istilah metodologi Islam dikenal dengan tahqīq al-mașālih (Afandi, 2011).

Dalam konteks di atas, DSN-MUI sebagai lembaga yang bertugas untuk 'mengawal' ekonomi syariah di Indonesia selalu aktif dalam melakukan inovasi produk jasa keuangan yang tujuannya adalah untuk memenuhi kebutuhan ekonomi masyarakat. Salah satu jenis produk yang terus diinovasi adalah $\dddot{i j a}>$ rah, dikembangkan dari konsepnya yang original dan didesain sesuai dengan konteks ekonomi modern. Sekali lagi, poros fatwa DSN-MUI adalah mașālị̣ al- 'ibād dengan mengacu pada nilai dan sistem syariah serta mendialogkannya dengan konteks Indonesia (Salahuddin: 2017).

Provinsi NTB, dengan masyarakat yang mayoritas muslim sepakat untuk mengembangkan potensi ekonomi berbasis nilai dan etika syariah. Kebijakan tentang pengalihan Bank NTB dari konvensional ke syariah, Pariwisata Halal, dan Gerakan Koperasi Syariah adalah beberapa kebijakan strategis NTB terkait dengan ekonomi syariah. Koperasi Syariah sebagai unit terkecil lembaga ekonomi dalam kebijakan strategis NTB adalah lembaga ekonomi yang dekat dan hidup di tengah masyarakat.

Sebagai bagian dari sistem ekonomi syariah, mau tidak mau koperasi syariah di NTB harus tunduk dan patuh pada Fatwa DSN-MUI terkait dengan pengelolaan produk jasa keuangan dan bisnis yang ada di Koperasi Syariah (Syariah \& Mui, 2012). Kesesuaian syariah dalam transaksi adalah bagian inti dari pertimbangan transaksi keuangan di lembaga keuangan syariah (Makkulau \& Abdullah, 2017). Bagaimanapun, keuntungan yang didapat melalui transaksi di lembaga keuangan syariah adalah berbeda dari lembaga keuangan konvensional (Stockman, 2000). Salah satu produk yang terus dimodifikasi, dan disesuaikan dengan konteks ekonomi-bisnis modern adalah Ijārah (MUI, 2017), dan kerapkali menjadi sorotan dalam praksis ekonomi masyarakat. Tulisan ini ingin menyoroti aplikasi Ijārah dan persepsi pengelola koperasi syariah di NTB tentang Ijärah. 


\section{TINJAUAN TEORITIS}

\section{Pengembangan Konsep Ijarah: Basis Metodologi}

Sesuatu yang berkembang hari ini, dan tidak dinyatakan tegas dalam alQuran-hadis, maka ketentuan dan aturan mainnya ditetapkan melalui proses ijtihad, dengan tatap mengacu pada nilai umum yang terkandung dalam alQuran-hadis. Ijtihad itu adalah aktivitas ilmiah untuk merespon perkembangan masyarakat dengan menggunakan perangkat metodologi uṣūl al-fiqh dalam wadah ijmā', qiyās, istiḥsān, mașlahah, al- 'urf dan lainnya.

Kalimat bijak al-Syahrastani, tatanāhā al-nuṣuṣ wa là tatanāhā al-waqā'i adalah dorongan kuat untuk melakukan aktivitas ijtihad. Dalam kata lain, ijtihad adalah spirit yang menghidupkan doktrin Islam dalam realitas kehidupan dan perkembangan masyarakat. Ijtihad juga yang memainkan peran untuk implementasi islām rahmatan li al- ‘̄alaminn, atau alislām șālị̣ li kuli zamān wa makān. Kesadaran spiritual dan intelektual adalah basis upaya gerakan ijtihad; menghadirkan islam yang inklusif untuk manusia dan kemanusiaan.

Salah satu masalah besar yang dihadapi umat manusia hari ini adalah terkait dalam bidang ekonomi. Kegagalan sistem ekonomi yang existed hari ini memicu hadirnya ekonomi Islam sebagai alternatif model pengembangan aset produksi, pola distribusi, dan komsumsi masyarakat menuju kesejahteraan ekonomi (state walfare). Untuk mewujudkan cita ekonomi Islam; ekonom, akademisi, praktisi, politisi, dan unsur masyarakat lainnya bersepakat untuk mendirikan lembaga keuangan syariah bank-non bank. Eksistensi lembaga keuangan syariah ini adalah simbol hadirnya sistem ekonomi Islam di antara sistem ekonomi lainnya.

Di Indonesia, untuk mengawal standar spiritual-intelektual operasional dan produk lembaga keuangan syariah 'dikawal' oleh lembaga DSN-MUI. Lembaga ini diamanahkan untuk memproduksi fatwa ekonomi yang berkaitan dengan pengembangan produk, sistem operasional, dan organisasi lembaga keuangan syariah. Apapun produk fatwa DSN-MUI selalu dijadikan referensi legal dalam operasional lembaga keuangan syariah. Dalam sejarah Indonesia, DSN-MUI adalah lembaga yang tergolong sangat produktif dalam menghasilkan fatwa. Ada beberapa hal yang menurut penulis sebagai sebab produktivitas fatwa DSN-MUI, yaitu sebagai berikut :

Pertama, sebagian besar masalah ekonomi adalah masalah yang masuk dalam kategori ijtihādiyāt, yang tidak ada ketentuannya secara rigid dalam alQuran dan hadis.

Kedua, permasalahan ekonomi adalah permasalahan yang berkembang cepat, dan membutuhkan jawaban (solusi) yang cepat pula. Perubahan peta dalam ekonomi melibatkan banyak unsur yang juga harus disisir secara rinci dalam sebuah jawaban fatwa. 
Ketiga, aktor fatwa dalam DSN-MUI adalah tokoh progressif yang merespon dengan cepat setiap perubahan/kebutuhan ekonomi masyarakat dalam kaitannya dengan lembaga keuangan syariah.

Dengan ketiga realitas di atas, DSN-MUI mendesain arsitektur ijtihad ekonomi melalui metode sebagai berikut, Taesīr al-manhaj, Tafrì al-halāl 'an al-harām, I'ādat alnaẓar, Taḥqiq al-manāṭ (Amin, 2012).

Metode di atas, berkaca pada pendapat ibn al-Qoyyim dalam berfatwa yang menyatakan bahwa fī tagayyur al-fatwā wa ikhtiläfihā bi ḥasbi al-azminah wa al-amkinah wa al-aḥwāl wa al-niyyāt wa al-'awă'id (Perubahan fatwa itu harus didasarkan pada lima pertimbangan; waktu, tempat, situasi, niat, dan adat). Rincian teknis pendapat Ibn al-Qayyim di atas dijabarkan oleh al-Qarāọāwi dalam karyanya Fatwa Kontemporer (Qarāḍ̄âwi, 2017).

Metode di atas dijalankan atas dasar kolektifitas dengan berbagai ragam jenis keahlian dan profesi mujtahid yang ada di dalamnya (Salahuddin, 2017). Masalah ekonomi yang ada (diajukan kepada DSN-MUI) dijawab secara kolektif oleh anggota komisi fatwa yang terdiri dari ulama, ekonom, ahli hukum, dan praktisi bisnis. Dalam bahasa uṣūl al-fiqh, apa yang dilakukan oleh DSN-MUI adalah ijmā, atau dalam bahasa ahli fikih modern dikenal dengan istilah ijtihād jamā'i. Apapun istilah ilmiah yang ditawarkan, yang pasti bahwa aktivitas fatwa DSN-MUI menunjuk pada satu perbuatan ittifáq ummati muhammadin ba'da wafatihi (kesepakatan yang dibuat oleh umat Muhammad setelah wafatnya beliau). Ijtihad fatwa tidak lagi didasarkan pada opini personal, namun mengarah pada kesepakatan komunal yang dikaitkan dengan sistem kemasyarakatan dan negara (Salahuddin, 2017). Ini juga dapat dipahami bahwa eksistensi DSN-MUI adalah sebagai sub-sistem dalam sistem yang lebih besar, yang mana fatwa juga turut sebagai variabel yang mempengaruhi sistem yang lebih besar (Auda, 2008).

Mekanisme kerja DSN-MUI dalam aktvitas ijtihad ekonomi terbagi menjadi 3 bagian yang penting (Mubarak, 2002). Pertama, dalam lembaga DSN-MUI ada tiga unsur atau elemen organisasi yang harus diperhatikan secara baik, yaitu DSN-MUI, Badan Pengurus Harian (BPH) DSN-MUI, dan Dewan Pengawas Syariah (DPS). Masing-masing elemen lembaga ini mempunyai wilayah dan tata kerja sendiri yang finalnya adalah menguatkan posisi lembaga DSN-MUI Kedua, BPH DSN-MUI yaitu lembaga operasional DSN-MUI yang menerima dan mengolah usulan/pertanyaan dari masyarakat untuk dijadikan sebagai memorandum (bahan acuan) dalam penetapan fatwa di DSN-MUI. Kemudian yang ketiga, DPS adalah lembaga yang dibentuk untuk mengawasi teraplikasinya fatwa DSN-MUI pada level operasional di lembaga keuangan syariah. 
Mekanisme tersebut merupakan standar operasional prosedur dalam melakukan ijtihad fatwa di lembaga DSN-MUI. Dengan metode ijtihad dan mekanisme yang ditetapkan, DSN-MUI melakukan penetapan, perubahan, dan pengembangan atas fatwa yang dikeluarkan. Orientasi perubahan adalah pemenuhan layanan jasa keuangan masyarakat baik yang sifatnya komsumtif, produktif, dan investasi.

\section{Paradigma Ijārah: Konsep Dasar dan Desain Pengembangan}

Pada dasarnya, Ijarah adalah kontrak bisnis yang masuk dalam kategori natural certainity contract. Prinsipnya hampir sama dengan murābaḥah, namun yang membedakannya adalah pada obyek transaksi. Perbedaan obyek transaksi inilah yang kemudian menghasilkan rumusan, konsep dan teori yang membedakan keduanya.

Para ahli menuliskan bahwa Ijärah adalah transaksi sewa-menyewa atas barang, atau upah atas jasa dalam batas waktu tertentu melalui pembayaran atau imbalan. Ijarah dimaknai sebagai akad pemindahan hak guna atas suatu barang atau jasa melalui pembayaran upah sewa, tanpa disertai pemindahan kepemilikan (al-milkiyyah) barang. Hanafiyah mendefinisikan Ijārah sebagai akad atas suatu kemanfaatan dengan penggantian. Sementara syāfi'iyyah merumuskan ija>rah sebagai akad atas suatu kemanfaatan yang mengandung maksud tertentu dan mubah, serta menerima pengganti atau kebolehan dengan penggantian tertentu. Mālikiyyah dan Hanābilah menuliskan Ijārah sebagai aktivitas untuk memiliki kemanfaatan yang mubah dalam waktu tertentu dengan pengganti (Syafe’i, 2001).

Dari uraian di atas, ada beberapa kata kunci terkait dengan Ijärah, yaitu akad, manfaat atas barang, uang pengganti, mubah, dan waktu tertentu. Dalam tradisi fikih klasik, batasan Ijārah dan muräbaḥah adalah jelas. Dan upaya untuk menggeser transaksi Ijärah (yang memiliki manfaat atas barang) ke transaksi muräbaḥah (hak memiliki atas barang) belum dirumuskan secara tegas. Hal ini bisa dipahami pola bisnis yang ada dan berkembang pada masa lalu masih sangat sederhana, sehingga rumusannya masih diklasifikasi sesuai dengan yang dipraktekkan dengan masarakat.

Dalam transaksi ekonomi bisnis modern, dikenal istilah leasing yang serupa dengan Ijārah. Bedanya, leasing memberikan peluang penyewa untuk memiliki barang yang disewanya. Sementara dalam Ijärah tidak diatur tentang kepemilikan atas barang. Sama halnya dalam kasus Ijärah dan muräbahah, dalam bisnis modern leasing dan kredit sangat tipis bedanya. Keduanya adalah transaksi jual-beli atas obyek tertentu dengan mekanisme yang berbeda. Pada sisi inilah, leasing dan Ijārah itu berbeda. Dan dari titik beda inilah 
kemudian DSN-MUI merancang Ijärah dan mengembangkannya sesuai dengan konteks bisnis modern.

Fatwa terkait dengan Ijärah di lembaga DSN-MUI tertuang dalam fatwa No. 9, 27, 41, 44, 101, 102, dan 112. Evolusi, atau pergeseran Ijärah dalam fatwa DSN-MUI adalah didasarkan pada pertimbangan sosio-ekonomi masyarakat. Hampir semua pengembangan atas skema Ijärah didasarkan atas permintaan pelaku usaha keuangan, dan trend usaha keuangan yang berkembang saat ini (Mubarok dan Hasanuddin, 2017). Hal ini juga bermakna bahwa ada proses dialogis yang mengawali fatwa, stimulus-respons. Dari segi teori akad, Ijärah multijasa pada prinsipnya merupakan pengembangan akad Ijärah, baik Ijärah atas barang (sewa) maupun Ijärah atas orang (buruh) serta terkoneksi dengan akad lain karena ragamnya objek yang diterima oleh nasabah. Ijārah multijasa juga merupakan bagian dari konsep multiakad (al-'uqūd al-murakkabah) bahkan malampaui konsep tersebut (Mubarok dan Hasanuddin, 2017).

Sementara cara penentuan ujrah, biasanya adalah berdasarkan kesepakatan antara mu’jir (pemberi sewa/koperasi syariah) dengan musta’jir (penerima sewa/anggota koperasi). Metode penentuan ujrah ini dilakukan dengan musāwamah dan syibh al-musāwamah (Mubarok dan Hasanuddin, 2017). Dengan demikian, penentuan ujrah ini bisa dilakukan dengan sangat fleksibel, sesuai dengan harga sewa di pasaran dan sesuai kebiasaan yang ada, secara lebih detail hal ini juga telah diatur ketentuan dalam perhitungan akuntasi syariah karena memiliki kemiripan dengan penentunan margin di jual beli murābaḥah.

Selanjutnya, dapat ditegaskan bahwa Ijārah multi jasa ini adalah turunan dari ijārah. Ijārah itu sendiri dapat dibagi menjadi beberapa bagian: Ijārah atas barang, Ijārah atas jasa (Ijärah multi jasa), ijärah muntahiya bi at-tamlik, dan ijarah mausufah bi al-zimah. Untuk memudahkan pemahaman terhadap macam-macam ijarah ini, diuraikan dalam tabel di bawah ini :

\begin{tabular}{|c|c|c|c|c|}
\hline No & Macam Ijarah & Karakteristik & $\begin{array}{l}\text { Pendapatan } \\
\text { Kopsyah }\end{array}$ & $\begin{array}{c}\text { Manfaat Bagi Anggota } \\
\text { Kopsyah }\end{array}$ \\
\hline 1 & $\begin{array}{l}\text { Ija }>\text { rah terhadap } \\
\text { Barang }\end{array}$ & Sewa Barang & Ujrah & Manfaat barang \\
\hline 2 & $\begin{array}{l}\text { Ija }>\text { rah terhadap Jasa } \\
\text { (Ijarah Multijasa) }\end{array}$ & Sewa Jasa & Ujrah & $\begin{array}{l}\text { Manfaat jasa tertentu, seperti } \\
\text { jasa kesehatan dan jasa } \\
\text { pendidikan }\end{array}$ \\
\hline 3 & $\begin{array}{l}\text { Ija }>\text { rah muntahiya bi } \\
\text { at-tamli }>k\end{array}$ & $\begin{array}{l}\text { Sewa Barang yang } \\
\text { diakhiri dengan } \\
\text { pemindahan } \\
\text { kepemilikan }\end{array}$ & Ujrah & $\begin{array}{l}\text { Manfaat barang dan } \\
\text { kepemilikan barang }\end{array}$ \\
\hline 4 & $\begin{array}{l}\text { Ijarah mausufah bi al- } \\
\text { zimah }\end{array}$ & Sewa tenaga kerja & Ujrah & $\begin{array}{l}\text { Selesainya } \\
\text { proyek }\end{array}$ \\
\hline
\end{tabular}




\section{METODE PENELITIAN}

Jenis penelitian ini jika dilihat dari sumber data termasuk kategori penelitian lapangan (field research), dengan pendekatan kualitatif, yaittu pendekatan ini berusaha memahami tingkah laku individu, fenomena, dan melihat secara mendalam tentang pengalaman, persepsi, pemahaman, pemberian arti, sekaligus mengungkapkan proses dan dinamika yang terjadi (Sarantakos, 1993).

Penelitian ini adalah penelitian sosio-economy yang memfokuskan diri pada pergeseran/pengembangan produk jasa keuangan mikro syariah di koperasi syariah Nusa Tenggara Barat. Perkembangan masyarakat pada satu sisi, dan kebutuhan akan layanan jasa keuangan syariah pada sisi lain, adalah dua hal yang secara konstan berkembang beriringan pada tataran sosial ekonomi.

Data utama dalam penelitian ini adalah data lapangan yang bersumber dari pengelola, konsumen, dan masyarakat pengguna jasa koperasi syariah. Data yang dikumpulkan adalah data tentang managemen sumber daya, managemen produk, dan managemen market. Sedangkan data skunder sebagai penguat analisis data utama didapat dari buku, jurnal, koran, dan referensi lain yang terkait dengan tema penelitian.

Dari total 330 koperasi syariah yang ada di NTB (Dinas Koperasi NTB, 2017), dipilih beberapa koperasi dengan kriteria sebagai berikut, yaitu koperasi telah berbadan hukum, dan diakui sebagai Badan Hukum Koperasi oleh masyarakat dan pemerintah, koperasi dinyatakan sehat secara kelembagaan oleh Dinas Koperasi Provinsi NTB dan Dinas Koperasi Kabupaten/Kota, dan koperasi syariah telah memberikan layanan Ijarah Multijasa di koperasi yang dikelolanya.

Dengan pola di atas, metode yang digunakan dalam menentukan subyek penelitian dengan menggunakan non-probability sampling, yaitu suatu teknik pengambilan sampel di mana peran peneliti sangat besar. Ciri umum dari teknik ini adalah bahwa tidak semua elemen dalam populasi mendapat kesempatan yang sama untuk menjadi informan (lawan dari teknik probability sampling).

Data dalam penelitian ini digali dengan metode observasi, wawancara, dan dokumentasi. Pertama, observasi dilakukan untuk menyoroti secara baik tentang koperasi syariah di NTB, khususnya terkait dengan ijarah multijasa. Dalam konteks ini yang diamati adalah relasi orang dalam koperasi yang meliputi pengelola koperasi, pengurus koperasi, anggota, dan masyarakat pengguna jasa koperasi. Kedua, wawancara mendalam yang dilakukan dengan beberapa informan inti, yaitu pimpinan dan pegawai koperasi syariah, anggota koperasi (pengguna produk ijarah multijasa), Dewan Pengawas Syariah (DPS), tokoh agama/akademisi, aparat pemerintah terkait (Dinas Koperasi dan UMKM setempat). Ketiga, 
metode dokumentasi yang digunakan untuk menelisik dokemen aplikasi produk/akad ijarah multijasa di koperasi syariah.

Analisis dilakukan seiring dengan proses pengumpulan data dengan mengkategorisasi, mereduksi, menafsirkan dan menyimpulkannya (Muhadjir, 1996). Validasi data dilakukan dengan trianggulasi, kecukupan referensi, pemeriksaaan teman sejawat, memperpanjang kehadiran peneliti, dan ketekunan pengamatan.

\section{HASIL DAN PEMBAHASAN}

\section{Praktek Ijarah Di Koperasi Syariah NTB}

Jumlah koperasi di NTB sebanyak 4.0oo lebih yang menyebar di kota dan kabupaten NTB. Varian dan jenis koperasi yang ada terdiri dari Koperasi Jasa, Koperasi Simpan Pinjam, Koperasi Pemasaran, Koperasi Konsumen, dan Koperasi Produsen. Keseluruhan koperasi di atas menyebar dalam unit sistem sosial masyarakat; seperti koperasi karyawan, koperasi pegawai, koperasi pengrajin, koperasi wisata, koperasi tani, koperasi ternak, koperasi wanita, dan lain-lain. Dari konteks ini dipahami bahwa ada kesadaran yang tinggi anggota masyarakat NTB dalam berkoperasi.

Dari populasi koperasi yang ada di atas, tidak lebih dari 40\% yang aktif melaporkan kegiatan koperasinya di masing-masing dinas koperasi kabupaten dan Kota. Dari 40\% koperasi yang melaporkan di atas, hanya sekitar 10\% lembaga koperasi yang dinyatakan sehat oleh Dinas koperasi NTB. Hal ini juga menunjukkan ada beberapa kendala yang terkait dengan sumber daya dan pebgelolaan koperasi yang ada di NTB. Walaupun beberapa upaya penguatan koperasi di NTB melalui pelatihan yang dilakukan oleh Dinas Koperasi NTB dan Dinas Koperasi di masing-masing Kabupaten/Kota sering dilakukan, belum mampu untuk menyelesaikan masalah yang dihadapi oleh koperasi.

Hasil pengolahan data dari informasi yang diberikan responden diketahui bahwa, terdapat beberapa hal yang menjadi sebab 'kegagalan' pengembangan koperasi yang baik di NTB, yaitu di antaranya adalah: Pertama, masyarakat kurang memahami makna dan filosofis berkoperasi. Karena itu koperasi hanya dijadikan sebagai wadah tempat berkeluh kesah ketika tidak punya uang. Kedua, etos masyarakat kita masih belum berpikir untuk memproduksi sesuatu. Baru sebatas untuk mengkomsumsi. Akibatnya, masyarakat belum berpikir bagaimana membesarkan lembaga koperasi yang mereka miliki. Koperasi hanya dijadikan sebagai tempat 'bergantung'. Ketiga, akibat dari itu semua, muncul 'gerakan lain' dari pengelola koperasi, dan mengubah haluan layanan koperasi yang seharusnya sebatas anggota menjadi layanan masyarakat umum.

Citra koperasi di masyarakat awam agak sedikit 'tercoreng' karena perilaku aktif beberapa pengelola kopersai. Hal ini tidak salah karena membaca dan menganalisis pasar 
yang dilakukan oleh pengelola koperasi dapat memberikan keuntungan bavi koperasi. Istilah 'bank subuh', 'bank ngengkeng' dan lain-lain adalah citra negatif yang disandingkan dengan praktek koperasi di NTB.

Dalam kondisi koperasi NTB yang demikian itu, pada tahun 2016 pemerintah NTB mencanangkan gerakan Ekonomi Syariah di NTB yang salah satu proyeknya-nya adalah koperasi syariah. Proyek koperasi syariah ini adalah mengupayakan koperasi yang sehat di NTB untuk merubah Badan Hukum menjadi Koperasi Syariah, atau mendirikan koperasi baru yang berbadan hukum koperasi syariah.

Pada awalnya, rata-rata pelaku usaha dalam lembaga koperasi syariah di NTB adalah kelompok idealis; $100 \%$ ingin mengaplikasikan konsep syari'ah dalam setiap transaksi, dan mengaplikasikan teori yang ada dalam realitas. Akan tetapi idealisme ini harus terhambat oleh realitas karena sumber daya yang serba kekurangan, baik dari pihak pengelola lembaga koperasi syari'ah maupun masyarakat. Yang utama adalah masyarakat. Pada intinya, konsep/sistem syariah menuntut adanya pribadi yang amanah, jujur, cerdas, dan berani. Pra kondisi inilah yang memungkinkan transaksi syariah murni dapat diaplikasikan.

Koperasi syariah adalah wujud idealisme masyarakat muslim NTB dalam berekonomi. Pengelolaan usaha yang ada di Koperasi Syariah pada hakekatnya berangkat dari konsepkonsep umum yang tertuang dalam Quran-hadist. Idealisme yang terbangun dalam pengelolaan Koperasi Syariah adalah sebagai berikut: Pertama, Islam memandang bahwa harta yang dimiliki manusia adalah titipan Allah. Oleh sebab itu, cara memperoleh, mengelola dan memanfaatkannya harus sesuai dengan tuntunan Islam. Kedua, Koperasi syariah mendorong anggota dan masyarakat untuk mengupayakan pengelolaan harta nasabah sesuai dengan ajaran Islam. Ketiga, Koperasi syariah memandang dan menempatkan karakter, sikap dan akhlāq al-karīmah sebagai point yang penting yang harus dimiliki oleh pihak nasabah dan pengelola lembaga keuangan, ekonomi, dan bisnis. Keempat, adanya kesamaan sikap dan ikatan yang emosional yang didasarkan pada prinsip keadilan, kesederajatan dan ketentraman antara pemegang saham, pengelola koperasi dan anggota atas kelangsungan usaha dalam aktivitas ekonomi koperasi syariah adalah dorongan lain yang memicu ghirah dalam menjalankan koperasi syariah.

Untuk mensosialisasikan idealisme di atas, pengelola Kperasi syariah melakukan beberapa hal, di antaranya adalah 1). Melakukan koordinasi dengan dinas Koperasi provinsi NTB dan Dinas Koperasi dan UKM di masing-masing Kota/Kabiupaten. 2). Mendirikan perhimpunan Koperasi Syariah NTB agar dapat menjalin kerjasama antar lembaga operasi dalam memperkuat jaringan dan kerjasama ekonomi. 3). Masing-masing Koperasi Syariah membangun jaringan masing-masing dan memperkuat anggota melalui kegiatan keagamaan 
dan sosial, 4). Menggandeng akademisi, tokoh agama, tokoh masyarakat, politisi, dan pejabat pemerintah. 5). Sosialasi melalui rumah, jamaah pengajian, dan membangun jaringan.

Sebagaimana disampaikan di atas, antusias masyarakat untuk berekonomi berbasis konsep syariah cukup baik. Walaupun dalam praktiknya, jika merujuk pada shariah complience (kepatuhan syariah), dalam menjalankan bisnis jasa keuangan masih perlu dipertanyakan. Keterbatsan sumber daya dan sumber dana seringkali menjadi alasan utama (Irwan, Yek Husen, Nasir, Irwan, 2018).

\section{Ijarah Multijasa di Koperasi Syariah NTB}

Mayoritas produk yang dikelola oleh koperasi syariah di NTB adalah untuk kebutuhan komsumsi. Hanya beberapa koperasi syariah yang concern untuk kegiatan ekonomi produktif. Kebutuhan komsumtif masyarakat dikelola melalui produk murābahah dengan fixed return. Walau tidak 100\% kebutuhan komsumtif untuk pengadaan barang, layanan pembiayaan komsumtif ini tetap saja menggunakan murābaḥah. Informan menuturkan:

"sebenarnya kita tahu kebutuhan anggota itu hanya sebagian kecil dari total pembiayaan untuk pengadaan barang. Sebagian lainnya itu untuk biaya sekolah, biaya berobat, atau biaya lain yang bukan untuk barang. Cuma masalahnya, masak kita harus merinci setiap kebutuhan itu dan memilah sesuai dengan kebutuhan pembiayaan. Di sini kita repotnya. Akhirnya kita pukul rata dengan murābahah"

Hal senada juga disampaikan oleh pengelola Koperasi Syariah Bina Laut yang mengatakan sebagai berikut :

"kebutuhan produksi untuk melaut rata-rata teman nelayan ini sudah punya. Sampan, bensin, jaring, dan lain-lain itu. Karena kadang-kadang kita dapat bantuan untuk alat-alat produksi itu. Cuma nelayan ini untuk di rumah yang tidak ada. Misalkan kalau anak sakit, istri melahirkan, keluarga meninggal, uang sekolah anak itu yang tidak ada. Ya, kita kasih saja pembiayaan dengan muräbahah supaya sederhana dan tidak ribet"

Berbeda halnya dengan informan lainnya yang menyatakan mereka secara tegas belum berani untuk mengaplikasikan produk ijärah. Aspek kehati-hatian lebih diutamakan. Jangan sampai masyarakat memahami pergantian istilah ujrah itu hanya sebagai hịlah untuk menggati kata bunga di koperasi konvensional.

Dari wawancara, sebenarnya yang dilakukan adalah praktek ijärah multijasa. Namun karena tradisi pembiayaan yang ada dan berkembang di masyarakat dengan pola kredit yang identik dengan murābaḥah, akhirnya layanan ijārah multijasa disetarakan dengan pembiayaan murābahah. 
Salah seorang informan dari Koperasi Syariah Al-Iqtishadi menuturkan hal yang berbeda. Dia mengatakan sebagai berikut :

"layanan pembiayaan yang ada di koperasi syariah itu tergantung pada jenis kebutuhan anggota sebenarnya. Nah, terkadang anggota tidak tahu jenis kebutuhannya sesuai dengan akad yang ada. Kita yang pengelola inilah yang mengarahkan akad yang digunakan. Kalau dia butuh jasa kepemilikan barang, kita arahkan ke muräbahah. Nah kalau dia membutuhkan uang untuk biaya nikah, biaya berobat, biaya sekolah dan lain-lain kita siapkan ijarah multijasa”

Hal senada juga disampaikan oleh informan dari koperasi yang berbeda, walaupun di koperasi yang mereka kelola belum melayani pembiayaan ijärah multijasa. Pembiayaan ijārah multijasa ini sangat cocok bagi karyawan, buruh, dan pegawai negeri. Informan dari Dewan Pengawas Syariah menuturkan lebih lanjut permasalahan ijārah multijasa yang di lembaga bank sangat rigid dan terbatas. Koperasi syariah semestinya dapat lebih elastis untuk mengembangkan produk ijärah multijasa.

Pemahaman yang sedikit berbeda disampaikan oleh salah seorang informan yang menjabat sebagai Ketua Koperasi yang mengatakan sebagai berikut:

"Pertama kami tidak menggunakan kata multijasa, karena pada saat bersama, kami memiliki pemikiran satu. Kita ambil ijarahitu sebenarnya dari kata jasa atas barang yang kita sewa, yang diperuntukkan untuk orang lain, ini jasa. Sebenarnya sewa sudah masukjasa di situ, dalam konteks pemikiran saya. itu sudah masukjasa. kita menyewakan sesuatu, pasti yang kita dapat bukan barangnya tetapi jasa atas penyewaan. Ini konteksnya. kalau dalam bahasa multijasa, di dalam DSN-MUI ada kata multijasa. itu artinya multi (banyak) jasa. Sedangkan di dalam fatwa digunakan satu akad. Kalau akad ijärahmaka pakai akad ijarah, kalau kafalah maka pakai akad kafalah. jadi kenapa saya gunakan bahasa itu (ijärah murni), karena jujur saya bingung dengan multijasa, sedangkan saya menggunakan satu akadjasa, yaitu jasa atas kemanfaatan dari pembiayaan yang kami berikan.”

Dari data di atas diketahui bahwa sebagian masyarakat pengelola koperasi syariah di NTB memahami ijārah multijasa. Walaupun sebagiannya belum mempraktekkan pembiayaan ijārah multijasa. Hanya saja, masalah yang muncul kemudian adalah terkait dengan operasional ijärah multijasa di koperasi syariah, dan besarnya ujrah yang ditetapkan atas jasa ijārah multijasa.

Secara umum operasional pembiayaan ijärah multijasa di Koperasi Syariah NTB dengan dua pola, yaitu pertama, pihak koperasi syariah memberikan langsung uang sewa (jasa) kepada pelaku usaha jasa (sekolah, rumah sakit, wedding organizer, dll) atas nama anggota yang mengajukan pembiayaan.

Prosedur pembiayaan ijärah multijasa pola pertama ini dipraktekkan sebagai berikut: "misalkan anggota membutuhkan pembiayaan untuk pendidian, maka kita akan membayarkan 
terlebih dahulu selaku koperasi kepada lembaga yang menyediakan layanan pendidian tersebut. Jika pembayaran kepada lembaga pendidikan tersebut selesai, maka baru akan dilanjutkan dengan ijarah kepada anggota tersebut. Jadi, pada intinya sudah harus selesai antara koperasi dengan lembaga pendidikan tersebut, kemudian baru dilanjutkan dengan koperasi dan anggota.

Kedua, pihak koperasi mewakalahkan kepada anggota untuk membayar jasa kepada pelaku usaha jasa. Pola yang pertama adalah pola ideal dan legitimate, sedangkan pola kedua adalah ijärah bi al-wakālah.

Proses pengajuan seperti biasa (umum) pengajuan, penentuan akad yang digunakan baru kemudian dilakukan survey untuk meyakini penggunaan akad tersebut, verifikasi syarat berkas pengajuan, setelah itu baru dilakukan relaisasi dan melihat dana yang siap untuk dilakukan realisasi." Selanjutnya, berkaitan dengan wakalah dalam produk ini, kami mengqiaskannya pada pembelian barang, karena memiliki persamaan komunitas (yang satu beli barang dan yang satunya lagi sewa barang atau sewa jasa). Jadi, kami berangkat dari hal tersebut dan kami melakukan pemisahaan antara wakalah dan ijarah dalam prakteknya. Kami melihat tidak ada sesuatu yang dilarang dalam transaksi ini.

Pola kedua ini adalah mengikuti pola (qiyās) dalam murābaḥah yang disertai dengan akad wakālah. Pola pertama dilakukan oleh Koperasi Syariah Al-Iqtishad dengan logika syari'ah. Sementara koperasi syariah lainnya menggunakan pola yang kedua, dengan pertimbangan sosiologis dan biaya aperasional. Hanya saja bagi Ikhwan, ketika ijārah multijasa itu diwakalahkan, anggota koperasi harus menyertakan bukti kuitansi pembayaran atas jasa yang dibutuhkan. Para pengelola koperasi syariah di NTB sepakat bahwa penyelewengan alokasi uang jasa yang diberikan kepada anggota akan batal demi hukum. Walau sepakat, semua pengelola koperasi syariah di NTB juga belum pernah meninjau kembali kepada anggota tentang penggunaan pembiayaan $\dddot{i j a}>$ rah multijasa. Fokus pengelola koperasi syariah adalah pada pembiayaan yang sehat, untuk sementara ini.

Penetapan atas jasa (ujrah) pembiayaan ijarah multijasa yang diambil dari anggota adalah sesuai dengan kesepakatan yang didasarkan pada estimasi, tradisi, dan kebiasaan yang sudah berlaku. Dalam hal ini, koperasi syariah di NTB menentukan besaran jasa antara 1,3\% s/d 2\% dari total pembiayaan yang diajukan dalam kurun waktu 10-12 bulan. Besaran fee/ujrah ini harus disepakati di awal, dan dikembalikan bersama pokok pembiayaan berbasis fixed return, sama dengan akad muräbahah. 
Secara konseptual, hampir semua pengelola koperasi syariah di NTB memahami ijārah dan pengembangan akad yang ada di dalamnya. Namun secara praktis, sebagian pengelola masih bersikap ihtiyāt (mempertimbangkan aspek kehati-hatian) dalam menawarkan produk ijärah. Aplikasi ijärah ini beda tipis dengan kredit yang telah dipraktekkan masyarakat pada umumnya. Pada sisi lain, ekonomi syariah hadir untuk mengikis praktek ekonomi keuangan sebelumnya. Praksis ijarah dengan hanya menggantikan istilah itulah yang dijaga oleh sebagian pengelola koperasi syariah di NTB.

\section{KESIMPULAN}

Pada dasarnya, semua yang terkait dengan muamalah (relasi kemanusiaan) itu adalah boleh, kecuali ada indikator pengerdilan martabat (nilai) kemanusiaan dalam aktivitas muamalah. Selama muamalah tidak bersinggungan nilai umum yang berlaku dalam masyarakat, tidak melanggar nilai agama dan hukum yang berlaku, dan dapat mensejahterakan hidup orang banyak (maslahat) maka dibutuhkan mekanisme untuk mempertahankan dan mengembangkan konsep muamalah yang dimaksud.

Ijärah adalah bagian dari muamalah, yang mekanisme pengembangannya dilakukan melalui lembaga DSN-MUI. Lembaga ini adalah lembaga ‘perwakilan' umat Islam Indonesia dalam bidang ekonomi. Mekanisme pengembangan ekonomi syariah melalui ijtihād jamā'i dalam lembaga DSN-MUI, selain mendapat pembenaran hukum legal di Indonesia juga mendapat pengakuan secara historis, teologis, dan tradisi keilmuan Islam. Pergeseran paradigma ijārah dengan mengikuti pola bisnis-ekonomi modern adalah bagian dari upaya pembuktian sejarah bahwa Islam dengan kerangka berpikir ekonomi dapat menyusup dan menyesuaikan diri dengan realitas perkembangan yang ada dalam masyarakat. Al-Islām șālị̣ li kulli zamān wa makān; Islām raḥmatan li al- ‘àlamīn.

\section{DAFTAR PUSTAKA}

Abdurrachman, A. (2008). Prosedur Penetapan Keputusan Fatwa Dewan Syariah Nasional. Al-Mawarid, Edisi XVII, 173-180.

Afandi, A. (2011). Maqasid Al-Shari'Ah Sebagai Filsafat Hukum Islam: Sebuah Pendekatan Sistem Versi Jasser Auda. Makalah.

Jasser Auda. (2013). An Islamic Perspective of Accounting: Introduction and Overview. Middle-East Journal of Scientific Research, 14.

LD Perda Nomor 8 Tahun 2018. (n.d.). 
Makkulau, A. R., \& Abdullah, M. W. (2017). Penerapan Prinsip Syariah Dalam Akad Pembiayaan Murabahah Pada Bank Muamalat. Jurnal Iqtisaduna, 3(1), 60.

Mubarak, Jaih. (2002). Metodologi Ijtihad Hukum Islam, Yogyakarta: UII Press.

Mubarok, Jaih dan Hasanuddin, (2017). Fikih Muamalah Maliyah: Akad Ijarah dan Ju'alah Bandung: Simbiosa Rekatama Media.

MUI, F. D. (2017). Fatwa DSN MUI Tentang Akad Ijarah. (021).

Pemerintah Provinsi Nusa Tenggara Barat. (2016). Peraturan Daerah Provinsi Nusa Tenggara Barat Nomor 2 tahun 2016 tentang Pariwisata Halal.1-16. Retrieved from https://jdih.ntbprov.go.id/?q=content/perda-no-2-tahun-2016

Qarāọāwi, Yūsu. al-Ijtihād al-Mu'āṣir, Mesir: Dār al-tauzī' wa al-Nasyr al-Islāmiyyah, 1994.

Qarāạāwi, Yusuf. Fatwa Fatwa Kontemporer, I, terjemahan As'ad Yasin, Jakarta: Gema Insani Press 1996.

Stockman, A. C. (2000). E Xchange R Ate S Ystems. 2O(1), 115-122.

Yulia, S. R. (2009). Jurnal Riset Akuntansi. I(1), 257-275.

Yulianti, R. T. (2007). Pola Ijtihad Fatwa Dewan Syari'ah Nasional MUI tentang Produk Perbankan Syari'ah. La_Riba, 1(1), 57-75.

Salahuddin, Muhammad (2012). Menuju Hukum Islam yang Inklusif-Humanistis: Analisis Pemikiran Jasser Auda tentang Maqashid al-Syariah. Ulumuna, https://ulumuna.or.id/index.php/ujis/article/view/105/95 (Vol. 16).

Salahuddin, Muhammad (2017). Maqashid al-Syariah dalam Fatwa Ekonomi DSN-MUI, Mataram, LP2M.

Salahuddin, Muhammad (2018). Ekonomi Syariah: Gerakan Arus Bawah, Mataram, FEBI UIN Mataram

Sadzali, Munawir. (1993). Ijtihad Kemanusiaan, Jakarta: Paramadina.

Sholihin, Ahmad Ifham. (2010). Pedoman Umum Lembaga Keuangan Syariah, Jakrta: Gramedia. 